\title{
A Note on Place Names, Currency, and Orthography
}

Come confusion may result from the toponym Rio de Janeiro in $\checkmark$ this study, because in common and formal usage it has referred to a variety of geographical and administrative units. Unless otherwise specified, Rio and the city of Rio interchangeably designate the administrative area formally separated from the surrounding province of Rio de Janeiro in 1834 . Since that time the area, the boundaries of which have changed little, has been variously designated the Corte (seat of the Royal Court), the Município Neutro (Neutral Municipality), the Federal District (after the establishment of the Republic in 1889), the state of Guanabara (from 1960 to 1975), and since 1975 the municipality of Rio de Janeiro within the state of the same name. When statistics, administrative jurisdiction, or narration of events refers to the urbanized downtown portion of the city (roughly bounded for much of the nineteenth century by four hills: Castelo, São Bento, Livramento, and Santo Antonio) or some other specific location, the area under discussion will be further specified. From 1834 to 1975 the capital of the surrounding province of Rio de Janeiro was the city of Niterói on the east side of Guanabara Bay, and Rio province was administratively distinct from the city of the same name. Any references to the province or locations in it are specifically designated as such in the text. 
Until 1942 the unit of Brazilian currency was the mil-réis, composed of one thousand réis and written 1\$ooo. (In 1942 the mil-réis became the cruzeiro, comprising one hundred centavos and written Cr\$1,oo.) In numerical notation, eight hundred réis (the daily wage of a military police soldier in 1860) was written $\$ 800$. At the average exchange rate for 1860 of $5^{2}$ U.S. cents to the mil-réis, the soldier's wage was roughly equal to 42 U.S. cents per day. Exchange rates with British pounds or U.S. dollars provide only an approximation of the local purchasing power of the wages and other monetary sums mentioned in this book, but the following series (from Duncan, Public, p. ${ }^{183}$ ) provides a rough guide:

\begin{tabular}{cc} 
Year & $\begin{array}{c}\text { Average value } \\
\text { of one mil-réis } \\
\text { in U.S. cents }\end{array}$ \\
\hline $183^{\circ}$ & $4^{6}$ \\
$184^{\circ}$ & 63 \\
$185^{\circ}$ & $5^{8}$ \\
1860 & $5^{2}$ \\
1870 & 45 \\
1880 & 45 \\
1890 & 46
\end{tabular}

One thousand mil-réis, in turn, was called a conto or conto de réis, written 1:00o\$ooo. As an example, for the fiscal year 1868-69 the total budget of the civil police system of Rio de Janeiro was $35^{8}$ contos, 660 mil-réis, and $75^{\circ}$ réis, written $35^{8: 660} \$ 75^{\circ}$. At the 1870 exchange rate of 45 cents to the mil-réis, that sum was roughly equivalent to US\$161,397.34. There is no meaningful cost of living series available to which these data might be compared, but whenever possible I have given a comparative context for the mil-réis figures mentioned in the text.

In an effort to reduce inevitable variation, and following editorial practice standard in Brazil, I have modernized the orthography and diacritical marks of most titles of sources, terms that for lack of an adequate English equivalent have been retained in the original Portuguese, and of proper names (except where the former spelling has been retained in Brazilian usage, e.g., Gilberto Freyre, rather than the technically correct modernization Freire). 
Place Names, Currency, and Orthography ^ xvii

Researchers in pre-twentieth century materials quickly adapt to the evolution from, for example, Nictheroy to Niterói, Castello to Castelo, Commercio to Comércio, Motta to Mota, Brazil to Brasil, and to the many other orthographic variations in the Portuguese language. 
